\title{
The effects of entrepreneurial orientation, social media, managerial ties on firm performance: Evidence from Vietnamese SMEs
}

\author{
An Thi Hong Nguyen ${ }^{a}$, Phuong V. Nguyen ${ }^{\text {** }}$ and Huynh Thi Sa Do ${ }^{a}$
}

${ }^{a}$ The School of Business, International University, Vietnam National University-Ho Chi Minh City, Vietnam ${ }^{b}$ Center For Public Administration, International University, Vietnam National University-Ho Chi Minh City, Vietnam

CHRONICLE ABSTRACT

\begin{tabular}{l} 
Article history: \\
Received: June 18, 2021 \\
Received in revised format: June \\
29,2021 \\
Accepted: September 6, 2021 \\
Available online: September 9, \\
2021 \\
\hline Keywords: \\
Entrepreneurial orientation \\
Social media \\
Managerial ties \\
Business ties \\
Political ties \\
Firm performance
\end{tabular}

\begin{abstract}
This study examines the effects of entrepreneurial orientation, social media, and managerial ties on the business performance of small and medium-sized enterprises (SMEs) in Vietnam. In addition, the mediating effects of social media and managerial ties on the causal relationship between entrepreneurial orientation and firm performance is investigated. A total of 180 senior managers of SMEs were collected for data analysis by using partial least squares structural equation modeling. The results reveal that entrepreneurial orientation strongly enhances social media and managerial ties, which are determinants of business performance. Specifically, entrepreneurial orientation has no direct impact on firm performance; but the mediating effects were confirmed. Based on the results, our study highlights some theoretical contributions and suggests practical implications for practitioners in Vietnamese SMEs to improve firm performance effectively and efficiently.
\end{abstract}

\section{Introduction}

Small and medium-sized enterprises (SMEs) are critical components of many countries around the world. This is due to their contribution to employment generation as well as regional growth and innovation (Wardati \& Mahendrawathi, 2019). They account for around $90 \%$ of enterprises and over $50 \%$ of employment in developing nations, and they contribute up to $40 \%$ of gross domestic product (GDP) (World Bank, 2020). Vietnam is no different; it is an emerging nation. In terms of employment creation, sustainable economic development, resource allocation, export expansion, equal income distribution, and support for regional development, SMEs play a critical role in the economy. According to the Vietnam Chamber of Commerce and Industry, 758,610 businesses were operating in Vietnam by the end of 2019. Whereas SMEs account for almost $95 \%$ of all companies. SMEs also accounted for around $45 \%$ of Vietnam's GDP and $31 \%$ of the country's total annual budget revenue, employing over five million people. SMEs provide significant contributions to the development of the Vietnamese economy, and they have the potential to grow in the coming years. However, SMEs in Vietnam continue to encounter numerous problems that result in poor performance and slow long-term economic development. As in many other countries, one common difficulty among SMEs is their economies of scale and limited resources compared to large organizations. As a result, SMEs have a higher risk of failure due to various challenges such as a lack of financing and management expertise (Amin, 2015); human resources and organizational resources; and a shortage of skilled workers (Wardati \& Mahendrawathi, 2019). As a result, in the face of severe competition, SMEs' chances of survival are exceedingly slim, leading to a significant focus on entrepreneurial orientation (EO) because of its vital role in increasing a business's ability to survive. To stay ahead of the

* Corresponding author.

E-mail address: nvphuong@hcmiu.edu.vn (P.V. Nguyen)

(C) 2022 by the authors; licensee Growing Science, Canada. doi: $10.5267 /$ j.ijdns.2021.9.004 
competition, they must focus heavily on altering organizational structures and commercial strategies. EO is essential for improving business performance. EO is defined as the set of processes, practices, and activities that lead to a company's willingness to act independently, innovate, take risks, and anticipate market opportunities (Lumpkin \& Dess, 1996). Specifically, with a predominantly collectivist Eastern culture and the second largest transitional economy in Asia after China, Vietnam is one of the under-researched economies in terms of entrepreneurial performance (De Jong, Tu, \& Van Ees, 2012).

Several studies have shown the causal relationship between EO and firm performance (Amin, 2015; Gupta, 2015). Notably, in previous studies on SMEs, there is a favorable association between EO and firm performance (Engelen, Gupta, Strenger, \& Brettel, 2015; Karami \& Tang, 2019; Thanos, Dimitratos, \& Sapouna, 2017). Overall, several prior studies have pointed out that businesses with entrepreneurial strategic orientations generate better performance (Amin, 2015; Rauch, Wiklund, Lumpkin, \& Frese, 2009; Wang, 2008; Venkatraman \& Prescott, 1990).

EO is a resource-intensive strategic orientation; without sufficient resource support, the performance implications of EO may be impeded (Jiang, Liu, Fey, \& Jiang, 2018). Therefore, more resources, possibly from social networks such as social media and managerial ties, appear to be necessary for EO success. First, firms with EO are more inclined to adopt new technologies such as social media since they can use it to achieve a first-mover advantage. Second, risk-taking entrepreneurs are willing to facilitate collaboration and use social media channels as a potential means of increasing performance. Finally, proactive entrepreneurs are more likely to utilize social media to communicate with customers about new products and services and respond to customer feedback (Valos, Polonsky, Mavondo, \& Lipscomb, 2015). Moreover, since industry restructuring and digital transformation are critical for promoting economic growth and offering more extensive globalization, strategic insights about SMEs' adoption of social media are crucial (Qalati, Yuan, Khan, \& Anwar, 2021).

Managerial ties is divided into two types: business ties, which involve connections with top managers at other firms, such as buyers, suppliers, and competitors, called horizontal connections; and political ties, which include connections with government officials, called vertical connections (Peng \& Luo, 2000). It is worth noting that institutional theory suggests that when an emerging economy transforms into a market-based economy, the role of ties becomes less critical. In contrast, marketbased capabilities have become dominant (Zhou, Li, Sheng, \& Shao, 2014). According to this theory, ties are intrinsically constrained by the limited number of personal ties that any individual can have, since building and maintaining the personal relationship is difficult and expensive (Peng, 2003).

Although social network theory and institutional theory can complement each other to explain the complex impacts of social media and managerial ties on firm performance, previous research has rarely combined these two theoretical perspectives to interpret a more complete picture of the compound effects of social media and managerial ties on firm performance in the SME context. This emphasizes the essential need to access the causal relationship between EO and firm performance under the mediating effects of social media and managerial ties.

The structure of this paper is as follows. The following section introduce the literature review and hypothesize the relationships between variables. Section 3 outlines the methodology employed in the study. The fourth section conducts data analysis and discusses the findings. Finally, the last section presents the conclusion.

\section{Literature review}

\subsection{Entrepreneurial orientation}

EO is considered as encompassing the processes, practices, and activities that result in firms' willingness to act independently, innovate, take risks, and proactively take advantage of market opportunities (Lumpkin \& Dess, 1996). EO enables enterprises to search for new market opportunities and improve existing fields of operation (Hult \& Ketchen Jr, 2001). Moreover, EO refers to the strategy-making procedures that give enterprises a foundation to make innovative, proactive, and risk-taking decisions and activities (Presutti \& Odorici, 2019; Rauch et al., 2009). Innovativeness reflects entrepreneurial orientation to engage in and encourage new ideas, experimentation, and creative process that might lead to new products, services, or technological progress. Proactiveness refers to entrepreneurial ability to anticipate customer demands for new business operations. Finally, while entrepreneurs' perspectives on the influence of risk on performance differ, business management is inextricably related to the assumption of risk (Aragón-Sánchez \& Sánchez-Marín, 2005). Firms with high EO are adept at establishing industrial configurations and modifying market conditions to their benefit, concentrating on bold and adventurous actions. However, EO is a resource-intensive strategic orientation; the performance implications of EO may be hampered without significant resource support (Jiang et al., 2018). Hence, more resources, possibly from external networks, appear to be particularly needed for EO success. This highlights the urgent need to evaluate the effectiveness of EO from the perspectives of managerial ties and social media.

\subsection{Entrepreneurial orientation and firm performance}

An entrepreneurial firm is willing to experiment with new products and technological processes, offer proactive advances to gain a competitive edge, and take on hazardous undertakings. As a result, EO encompasses at least three dimensions: innovation, proactiveness, and risk-taking (Lumpkin \& Dess, 1996). In other words, entrepreneurially oriented firms are highly proactive in response to market opportunities and bear high risks; simultaneously, their flexibility allows them to adapt to a 
dynamic competitive environment, shape and adjust the environment, and exploit uncertain opportunities (Covin \& Slevin, 1989). A substantial body of research shows that EO positively influences firm performance (Amin, 2015; Gupta, 2015). This positive relationship between EO and firm performance holds true in studying on SMEs (Engelen et al., 2015; Karami \& Tang, 2019; Thanos et al., 2017). All the prior studies support the traditional beliefs of EO. Therefore, in this study, we pursue the traditional and well-known approach to investigating EO and treating firm performance as a context in which EO substantially impacts SME performance. In line with previous studies, it is hypothesized that:

\section{$\mathbf{H}_{1}$. EO has a positive relationship with firm performance.}

\subsection{Social media}

Using cyberspace and web technology has become standard practice in all enterprises in recent decades. Enterprises are empowered to contact their customers anytime from any area by Internet (Chen, Fay, \& Wang, 2011). Social media is defined as a set of Internet-based tools to establish public membership in creating a business network and develop content through interaction and collaboration (Mount \& Martinez, 2014). Social media involves various types of online applications such as social network sites, blogs, forums, microblogs, photo and video sharing, product and service reviews, evaluation communities, and social gaming (Aichner \& Jacob, 2015). Individuals can use social media to share information and create content quickly (Kim \& Park, 2013). Individuals use Facebook, YouTube, Wikipedia, Twitter, Instagram, TripAdvisor, online forums, ratings and review boards, and other online networks to share their experiences and engage with other users (Chen et al., 2011).

On the one hand, social media attracts information searchers who want to learn more about the product or service they want to buy, which leads to an increase in consumer purchasing intention (Hajli, 2014). On the other hand, social media as a communication platform assists enterprises in achieving a variety of organizational goals, including marketing, public relations, advertising, branding, customer service, human resources, and issue resolution (Kim \& Park, 2013). Furthermore, social media impacts a company's brand positioning, brand awareness, consumer loyalty, and purchase decisions (Nisar \& Whitehead, 2016). Social media has been seen as an effective platform for businesses to engage with a considerable number of potential clients in order to disseminate business information (Schaupp \& Bélanger, 2014; Tajvidi \& Karami, 2021) and create value for the organization in terms of social media value (Schaupp \& Bélanger, 2014). Firms' adoption of social media builds fantastic networks among organizations, customers, and suppliers (Siamagka, Christodoulides, Michaelidou, \& Valvi, 2015). Firms that utilize a network approach benefit from networking activities that lead to improved performance (Naudé, Zaefarian, Najafi Tavani, Neghabi, \& Zaefarian, 2014). The majority of prior research on networking approaches focused on the benefits of networking for businesses (Ladkin \& Buhalis, 2016; Naudé et al., 2014; Trainor, Andzulis, Rapp, \& Agnihotri, 2014). Previous studies have concentrated on the online networking benefits for SME performance (Hajli, 2014; Tajvidi \& Karami, 2021). Given that SMEs are the driver of economic growth and innovation of most countries, previous research has substantially concentrated on the usage (Qalati et al., 2021; Trainor et al., 2014) and benefits and barriers (Michaelidou, Siamagka, \& Christodoulides, 2011) of social media in the business context of SMEs. Moreover, empirical results also confirm the positive relationship between social media adoption and firm performance in the SME context (Chatterjee \& Kumar Kar, 2020; Dutot \& Bergeron, 2016; Qalati et al., 2021; Wardati \& Mahendrawathi, 2019). However, regarding the strategic orientation, there has been little consideration of the impact of social media on enhancing SME performance when pursuing EO. First, firms with EO are more likely to adopt new technologies like social media because they can utilize social media to gain a first-mover advantage. Second, risk-taking entrepreneurs are willing to facilitate cooperation and implement social media channels as a potential opportunity for improving performance. Finally, by being proactive, entrepreneurs are more likely to use social media to communicate with customers regarding new products and services and respond to customer feedback (Valos, Polonsky, Mavondo, \& Lipscomb, 2015). However, In some recent studies, scholars find that EO is not statistically significant effect on the business performance of SMEs (Karami \& Tang, 2019; Nguyen, Huynh, Lam, Le, \& Nguyen, 2021). Meanwhile, another study on SMEs in Vietnam illustrates that all three dimensions (innovativeness, proactiveness, and risk-taking strategies) of EO positively impact firm performance (Luu \& Ngo, 2019). Moreover, Lee and Chu (2017) provide evidence to support the positive relationship between EO and firm performance when testing sub-samples of family firms. In contrast, this relationship becomes insignificant when testing sub-samples of nonfamily firms. Therefore, the extant literature shows inconsistent results on the impact of EO on SME performance.

From the literature review, social media has been released as an essential influence on entrepreneur behavior. Several factors have influenced entrepreneur adoption and use of social media, which can be roughly classified as technological, organizational, individual, and environmental factors (Olanrewaju, Hossain, Whiteside, \& Mercieca, 2020). However, it is necessary to examine the social media platform usage by SMEs by concentrating both EO and firm performance. In line with prior research, this study proposes the following hypotheses:

\section{$\mathbf{H}_{2}$ : EO has a positive impact on social media.}

\section{$\mathbf{H}_{3}$ : Social media has a positive impact on firm performance.}

\subsection{Managerial ties}

Executives' interactions with external entities in their work surroundings are referred to as managerial ties. Managerial ties is divided into two types: business ties, which involve connections with top managers at other firms, such as buyers, suppliers, 
and competitors, called horizontal connections; and political ties, which include connections with government officials, called vertical connections (Peng \& Luo, 2000). Managerial ties have long been thought of as a source of social capital, expressed in the links and networks of interfirm relationships that result in economic actions (Lee, 2019; Peng \& Luo, 2000; Uzzi, 1996). It implies that managers bestow the social capital inherent in their networks to achieve the business objectives. Therefore, managerial ties have gotten a lot of attention, and scholars are still working on them (Lee, 2019; Luu \& Ngo, 2019; Zhang, Zhao, Gao, \& Xiao, 2020). According to social network theory, managerial ties offer entrepreneurs valuable resources, expertise, information, and privileges such as exclusive opportunities and legitimacy (Zhang, Soh, \& Wong, 2010; Zhang et al., 2020). Managerial ties also increase network member exchange and collaboration by lowering transaction costs and reducing opportunism (Sheng, Zhou, \& Li, 2011). As a result, managerial ties play an important role in increasing the survival and growth of new ventures (Peng \& Luo, 2000). Managerial ties enable entrepreneurs to improve product innovation, exploit opportunities, and gain a competitive edge, but this help comes in various forms (Gao, Shu, Jiang, Gao, \& Page, 2017). However, available empirical results are varied across market environments; hence, it is unclear whether political and business ties have a beneficial or detrimental impact on firm performance (Luo, Huang, \& Wang, 2012). It is proposed that the effects of managerial ties on firm performance vary depending on the ownership type or structure (Luo et al., 2012; Peng \& Luo, 2000). Managerial ties may potentially pose a threat to the effectiveness of EO measures. Establishing and maintaining managerial ties necessitates significant investments, which can strain businesses with limited finances, particularly in transitional and collectivist economies. Furthermore, having too much information and resources can lead to a glut of information and resources, as well as a longer processing time, slowing enterprises' responses to quickly changing markets in transitional economies (Adler \& Kwon, 2002). Meanwhile, many EO enterprises in transitional, collectivist economies invest heavily in managerial ties in the hopes of improving their performance. The potential risks of social capital from managerial ties necessitate further research into how social capital from managerial ties possibly enhances the performance effects of EO strategies. Based on the above literature, we propose the following hypotheses:

\section{$\mathbf{H}_{4}$ : EO has a positive effect on managerial ties.}

\section{H5: Managerial ties have a positive effect on firm performance.}

The research model with five proposed hypotheses is illustrated in Figure 1. This model is integrated with social network theory and institutional theory; it investigates the direct and indirect impacts of EO on firm performance under the mediating effects of social media and managerial ties.

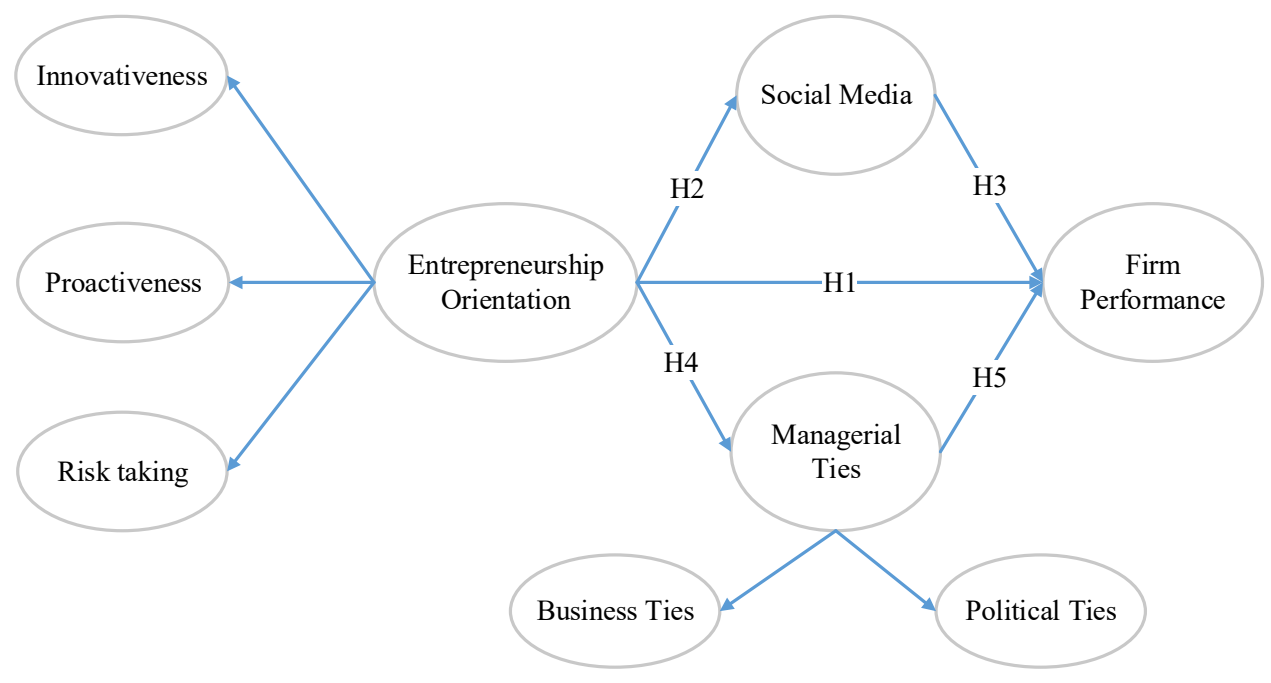

Fig. 1. Research model

\section{Methodology}

\subsection{Questionnaire design}

Overall, 30 items comprising four constructs adapted from previous studies are measured. Specifically, entrepreneurial orientation as a second-order construct, including three subconstructs (Innovativeness, proactiveness, and risk-taking), consists of nine items adapted from Covin \& Slevin (1989) and Lumpkin and Dess (1996). Social media is addressed using nine items adapted from prior studies (Dutot \& Bergeron, 2016; Parveen, Jaafar, \& Ainin, 2016). Six items are used for managerial ties as a second-order construct, including two subconstructs (business ties and political ties). These measures were followed previous studies (Li, 2005; Peng \& Luo, 2000). Finally, business performance is measured with six items adapted from Luu \& Ngo (2019). 
Our questionnaires include two main parts: demographic information and measurement items. In the first part, respondents were asked to provide their gender, age, position, type of enterprise, firm age, and a number of employees. In the second part, respondents were asked to read and select one number representing their opinion on the given statements, which were measured items ranging from 1 to 5 ("strongly disagree" to "strongly agree"). The questionnaires are available for respondents to complete in both English and Vietnamese. The Vietnamese version, which was translated and adapted for the Vietnamese context with some adjustments, helps to ensure respondents' understanding. Subsequently, minor changes were made to ensure that the meanings of the questionnaire in both English and Vietnamese versions were compatible.

\subsection{Data collection}

This study uses a self-administered survey method and a convenience sampling approach. We have permission granted from graduate program directors of three largest MBA programs in Ho Chi Minh City, Vietnam, to visit several classes to distribute the questionnaire and come back after one week to collect the result. Some MBA students asked us to provide an online survey via the google form. It enables them to conduct and spread out the questionnaire more conveniently. Some MBA students who are senior managers can complete the survey without getting approval from their managers. However, many MBA students have not known how to ask some critical questions. They helped us to ask their senior managers to conduct the questionnaire. Finally, data collection was conducted over the course of five months, from September 2019 to January 2020. During this period, 380 questionnaires were distributed in both the online and offline approaches. Eventually, a sample size of 180 was used for this study.

\subsection{Data analysis}

Partial least squares structural equation modeling (PLS-SEM) was selected as an analytical technique and performed using SmartPLS software version 3.0 (Ringle, Wende, \& Becker, 2018). There are two reasons that PLS-SEM is appropriate for our study. First, it enables structural model analysis with a small sample size (Hair, Risher, Sarstedt, \& Ringle, 2019), which is appropriate for this study's sample size of 180. Moreover, PLS-SEM is also an excellent option for a complex model with limited literature (Hair et al., 2019). PLS-SEM separately examines the measurement and structural models, ensuring scientific reliability (Ringle \& Sarstedt, 2016). Therefore, we chose PLS-SEM for conducting path analysis.

\section{Results}

\subsection{Demographic information}

Table 1 provides six types of demographic information: gender, age, position, four types of the enterprise (private enterprise, limited liability company, joint-stock company, and joint venture company), firm age, and a number of employees. There are two age groups 25 to 40 and above 40 with the former accounting for $56.70 \%$ of the total respondents, and the latter $43.30 \%$. The percentage of female respondents $(52.58 \%)$ is higher than that of male respondents $(47.42 \%)$. The proportions in terms of job position-director or chief executive officer (CEO) and managers are $20.52 \%$ and $79.48 \%$, respectively. Among the four types of enterprises, more than $96 \%$ belong to private, limited liability, and joint-stock companies. Additionally, nearly half of enterprises in the survey have been operating for more than five years and $31.40 \%$ for under three years. The categories for several employees are less than 50, 51 to 200, and more than 200, of which the highest percentage is $40.30 \%$ (less than 50 employees), and the lowest is $26.50 \%$ (above 200 employees).

Table 1

Demographic Information

\begin{tabular}{|c|c|c|}
\hline , & istics $(\mathrm{N}=180)$ & Percentage $(\%)$ \\
\hline \multirow{2}{*}{ Age } & From 25 to 40 & $56.70 \%$ \\
\hline & Above 40 & $43.30 \%$ \\
\hline \multirow{2}{*}{ Gender } & Male & $47.42 \%$ \\
\hline & Female & $52.58 \%$ \\
\hline \multirow{2}{*}{ Position/ Level } & Director/CEO & $20.52 \%$ \\
\hline & Manger & $79.48 \%$ \\
\hline \multirow{4}{*}{ Business type } & Private Enterprise & $34.70 \%$ \\
\hline & Limited Liability Company & $32.30 \%$ \\
\hline & Joint Stock Company & $29.50 \%$ \\
\hline & Joint Venture Company & $3.50 \%$ \\
\hline \multirow{3}{*}{ Firm age } & Less than 3 years & $31.40 \%$ \\
\hline & From 3 years to 5 years & $25.70 \%$ \\
\hline & More than 5 years & $42.90 \%$ \\
\hline \multirow{3}{*}{ Number of Employees } & Less than 50 & $40.30 \%$ \\
\hline & From 51 to 200 employees & $33.20 \%$ \\
\hline & Above 200 employees & $26.50 \%$ \\
\hline
\end{tabular}

\subsection{Measurement model}

PLS-SEM is conducted to test our research model by using the SmartPLS 3.0 software. One advantage of the PLS-SEM approach is that it allows for a separate examination of measurement models and structural models, rather than a simultaneous 
examination (Hair et al., 2019). Its scientific reliability was proven in a study by Ringle and Sarstedt (2016). Moreover, this approach is usually applied for complex models with many constructs and indicators or a relatively small sample size because it demonstrates higher reliability than covariance-based SEM (Hair et al., 2019). This study implemented a Consistent PLSSEM technique by using SmartPLS software to conduct the path analysis of the research model. By doing so, it satisfied a solid theoretical foundation and validity (Cheah et al., 2018; Nguyen et al., 2021). We conducted a confirmatory factor analysis to evaluate the validity of measures. The results are reported in Table 2 and showed that all factor loadings were within an acceptable range, varying from 0.712 to 0.932 (greater than the threshold of 0.7), except for item of "EO9- Although the costs for some projects are high, our organization will still launch those projects." The reliability of the measures was tested. The composite reliability values and Cronbach's alpha values all exceed the thresholds of 0.7 , which identified good reliability (Hair et al., 2019). The convergent validity of measures was assessed based on the constructs' average variance extracted (AVE) values, which should be at least 0.5 . The results of AVE values illustrated that all constructs met or exceeded the minimum threshold, ranging from 0.569 to 0.654 . Thus, reliability and convergent validity were ensured.

Table 2

Construct reliability and validity

\begin{tabular}{|c|c|}
\hline Constructs & Standard loading \\
\hline \multicolumn{2}{|l|}{ Entrepreneurial orientation (EO) $(\alpha=0.892 ; \mathrm{CR}=0.914 ; \mathrm{AVE}=0.570)$} \\
\hline \multicolumn{2}{|l|}{ Innovativeness (subconstruct) } \\
\hline EO1- We constantly emphasize and improve innovativeness, R\&D, and technological leadership & 0.740 \\
\hline EO2- Within the last three years, we have experimented and brought several new products or services to the market & 0.817 \\
\hline EO3- Our company is known as an innovator among businesses in our industry thanks to the development of new methods and & 0.849 \\
\hline \multicolumn{2}{|l|}{ Proactiveness (subconstruct) } \\
\hline EO4- We constantly seek new opportunities before our competitors & 0.835 \\
\hline EO5- Our company wants to become the first business to introduce new products or services, administrative techniques, operat- & 0.884 \\
\hline EO6- We opportunistically shape our business environment to enhance our presence in the market & 0.888 \\
\hline \multicolumn{2}{|l|}{ Risk-taking } \\
\hline EO7- Top managers of our company generally is willing to invest in high-risk projects & 0.909 \\
\hline EO8- A strong tendency to take risks is our business strategy & 0.907 \\
\hline EO9- Although the costs for some projects are high, our organization will still launch those projects & Eliminated \\
\hline \multicolumn{2}{|l|}{ Social media $(\mathrm{SM})(\alpha=0.913 ; \mathrm{CR}=0.928 ; \mathrm{AVE}=0.591)$} \\
\hline \multicolumn{2}{|l|}{ The presence and adoption of social media allows our business to } \\
\hline SM1- promote and innovate our new products & 0.794 \\
\hline SM2- increase the visibility of the company & 0.801 \\
\hline SM3- develop stronger customer relationship management & 0.780 \\
\hline SM4- improve our database of customer & 0.803 \\
\hline SM5- improve our sales & 0.748 \\
\hline SM6- increase higher brand reputation & 0.778 \\
\hline SM7- share, search information, and accessibility in the company & 0.712 \\
\hline SM8- advance advertising and promotion & 0.740 \\
\hline SM9- conduct market research and development & 0.757 \\
\hline \multicolumn{2}{|l|}{ Managerial ties (MT) $(\alpha=0.848 ; \mathrm{CR}=0.888 ; \mathrm{AVE}=0.569)$} \\
\hline \multicolumn{2}{|l|}{ Business ties (subconstruct) } \\
\hline \multicolumn{2}{|l|}{ The degree that the top managers of our business have actively utilized and built personal ties, networks, and connections dur- } \\
\hline MT1- Top managers at buyer firms & 0.804 \\
\hline MT2- Top managers at supplier firms & 0.847 \\
\hline MT3- Top managers at competitor firms & 0.877 \\
\hline \multicolumn{2}{|l|}{ Political ties (subconstruct) } \\
\hline \multicolumn{2}{|l|}{ The degree that the top managers of our business have actively utilized and built personal ties, networks, and connections dur- } \\
\hline MT4- Political leaders in various levels of the government & 0.858 \\
\hline MT5- Officials in industrial bureaus & 0.932 \\
\hline MT6- Officials in regulatory and supporting organizations such as tax bureaus, state banks, commercial administration bureaus, & 0.898 \\
\hline \multicolumn{2}{|l|}{ Business performance $(\mathrm{BP})(\alpha=0.893 ; \mathrm{CR}=0.919 ; \mathrm{AVE}=0.654)$} \\
\hline \multicolumn{2}{|l|}{ During the past 3 years, our business has: } \\
\hline BP1- met revenue goals & 0.809 \\
\hline BP2- met sales growth goals & 0.770 \\
\hline BP3- met market share goals & 0.844 \\
\hline BP4-met return on investment goals & 0.846 \\
\hline BP5- met profitability goals & 0.808 \\
\hline BP6- Achieved customer satisfaction goals & 0.720 \\
\hline
\end{tabular}

Discriminant validity was evaluated by using the Fornell-Larcker criterion as well as the Heterotrait-Monotrait ratio (HTMT), the former of which was proposed by Fornell and Larcker (1981) and the latter of which was introduced by Henseler, Ringle and Sarstedt (2015). Specifically, Fornell and Larckers's metric requires that the square root of AVE be greater than the estimated correlation values, which is demonstrated in Table 3. 
Table 3

Fornell-Larcker Criterion

\begin{tabular}{lrrr} 
& $\mathbf{1}$ & $\mathbf{2}$ & $\mathbf{3}$ \\
\hline 1. Entrepreneurial Orientation & $\mathbf{0 . 7 5 5}$ & & \\
2. Firm Performance & 0.597 & $\mathbf{0 . 8 0 1}$ \\
3. Managerial Ties & 0.603 & 0.481 \\
4. Social Media & 0.758 & 0.631 & 0.754 \\
\hline Notes: the square root of AVE on the diagonal. & & $\mathbf{0 . 7 6 9}$ \\
\hline
\end{tabular}

According to Henseler, Ringle and Sarstedt (2015), HTMT values should be below 0.85. The results of our discriminant validity evaluation by using the HTMT criteria are presented in Table 4, which indicates that all values were below 0.85 . Therefore, we ensured discriminant validity, as all values surpassed the required criteria of the two assessments, as demonstrated in Table 3 and Table 4.

Table 4

Heterotrait-Monotrait Ratio (HTMT)

\begin{tabular}{lrr} 
& $\mathbf{2}$ & $\mathbf{2}$ \\
\hline 1. Entrepreneurial Orientation & $\mathbf{3}$ & Criteria $<0.85$ \\
2. Firm Performance & 0.662 & \\
3. Managerial Ties & 0.695 & 0.546 \\
4. Social Media & 0.832 & 0.692 \\
\hline
\end{tabular}

\subsection{Testing results}

The coefficient of determination $\left(R^{2}\right)$ is used to measure the explanatory power of a model. According to the results, the $R^{2}$ values of constructs ranged from 0.363 to 0.575 , ensuring the model's explanatory power (Hair et al., 2019). As illustrated in Table 5, most of the proposed hypotheses were accepted except for $\mathrm{H} 1$, whose $p$-value was greater than 0.1 . Specifically, the results indicated a significant relationship between entrepreneurial orientation (EO) and social media (SM), which had the highest coefficient (0.838), while the impact of EO on managerial ties (MT) was 0.692. Additionally, SM and MT were both significant indicators of firm performance (FP), with coefficients of 0.526 and 0.246 , respectively.

Table 5

Path estimated results

\begin{tabular}{cccc}
\hline & Hypotheses & Estimates & P Values \\
\hline H1 & EO $\rightarrow$ FP & 0.058 & 0.808 \\
H2 & EO $\rightarrow$ SM & 0.838 & 0.000 \\
H3 & SM $\rightarrow$ FP & 0.526 & Rejected \\
H4 & EO $\rightarrow$ MT & 0.692 & 0.005 \\
H5 & MT $\rightarrow$ FP & 0.246 & 0.000 \\
\end{tabular}

Table 6 presented the results from testing mediating effects. There is no direct effect from EO to FP. Meanwhile, the indirect effect of entrepreneurial orientation on firm performance via social media and managerial ties are statistically significant. Since EO has no direct impact on FP, the mediators as social media and managerial ties have full mediation effects with indirect-effect path coefficients of $0.165^{* * *}$ and $0.084^{* * *}$, respectively.

Table 6

Results of mediating effects.

\begin{tabular}{llll}
\hline \multicolumn{1}{c}{ Path } & \multicolumn{1}{c}{ Direct } & Hotirect & Hypothisis/Mediating test results \\
\cline { 2 - 4 } & Std. Coeff. & Std. Coeff. & No effect \\
\hline $\mathrm{EO} \rightarrow \mathrm{BP}$ & 0.058 & & Indirect effect (Full mediation) \\
$\mathrm{EO} \rightarrow \mathrm{SM} \rightarrow \mathrm{FP}$ & 0.058 & $0.165^{* * *}$ & Indirect effect (Full mediation) \\
$\mathrm{EO} \rightarrow \mathrm{MT} \rightarrow \mathrm{FP}$ & 0.058 & $0.084^{* * *}$ & \\
\hline Notes: Significant level: $* * * \mathrm{p}<0.01$. Std. Coeff. (Standard Coefficient) &
\end{tabular}

\section{Discussion and implications}

The current research extends the literature of EO by evaluating the role of social media and managerial ties on the relationship between EO and SME performance in the context of a transitional, collectivist economy. Most previous studies largely either consider three dimensions (innovativeness, proactiveness, and risk-taking strategies) of EO as independent variables (Amin, 2015; Buli, 2017; Luu \& Ngo, 2019) or combine all measures of EO as one latent variable (Jiang et al., 2018; Karami \& Tang, 2019; Lee \& Chu, 2017; Presutti \& Odorici, 2019; Tajeddini \& Ratten, 2020). Among a few studies, this paper constructs EO as a second-order factor with three subconstructs, including innovativeness, proactiveness, and risk-taking. Moreover, we also differentiate from previous studies (Lee, 2019; Luu \& Ngo, 2019; Zhang et al., 2020) in building managerial ties as a secondorder construct with two subconstructs of business ties and political ties. As a result, this paper proposed a new theoretical model integrating social network theory and institutional theory; we investigate EO's direct and indirect effect on firm performance through two mediators, including managerial ties and social media. Our theoretical discussion and empirical findings contribute to the literature from various perspectives. 
First, our findings illustrate that EO has no direct effect on SME performance. This result is unexpected because many prior studies support the causal relationship between EO and firm performance in the SME context (Engelen et al., 2015; Karami \& Tang, 2019; Thanos et al., 2017); but it is in line with the recent studies (Karami \& Tang, 2019; Nguyen et al., 2021). It is worth noting that SMEs with high EO can create industrial configurations and reshape market conditions to their advantage by focusing on risky and adventurous activities. Nevertheless, EO is a resource-intensive strategic orientation; without sufficient resource support, the performance implications of EO may be impeded (Jiang et al., 2018). Specifically, the greater resources, presumably from external networks, appear to be critical for the success of EO. Hence, the role of EO in facilitating firm performance can be affirmed when investigating the mediating effects of social media and managerial ties, it is important to keep in mind that.

Second, the indirect effect of entrepreneurial orientation on firm performance via social media and managerial ties are statistically significant. The findings confirm the role of two mediators, including social media and managerial ties. It means that an underlying mechanism via which EO indirectly enhances firm performance is the advantage to access and acquire valuable resources from social media and managerial ties. The EO studies that have already looked at mediating pathways have typically investigated issues that are internal to the enterprise (Jiang et al., 2018). Without taking into account the external social network framework in which businesses operate. We emphasize the necessity to reassess the impact of EO, giving particular emphasis to its function in changing the attractiveness of network resources in terms of social media and managerial ties, in line with network theory. This network strategy helps to explain why some businesses with little internal resources can yet achieve their entrepreneurial goals. While it is widely acknowledged that EO encourages greater experimentation, supports new ideas, and generates operation processes that can lead to the development of new products, services, or technological progress (Presutti \& Odorici, 2019; Rauch et al., 2009). We suppose that SMEs can utilize social media and managerial ties to implement each dimension of EO to facilitate business performance simultaneously.

Third, in line with former studies, EO has a substantial impact on social media (Dutot \& Bergeron, 2016; Valos et al., 2015). SMEs that implement EO put a strong emphasis on seeking new external opportunities. These are incorporated internally through systematic organizational change. When it comes to social media implementation, EO connects the internal organization with the external environment, which has been noted as a challenge (Valos et al., 2015). EO is the second-order construct in our integrated model, including three subconstructs (innovativeness, proactiveness and risk-taking). In terms of innovativeness, SMEs with EO are more inclined to adopt new technology such as social media since they may use it to achieve a first-mover advantage. In terms of risk-taking, entrepreneurs willing to take risks are eager to enable collaboration and utilize social media channels as a potential means of enhancing performance. Finally, entrepreneurs who are proactive are more likely to utilize social media to connect with customers about new products and services, as well as to respond to customer feedback. Fourth, consistent with our prediction, EO exerts a positive effect on managerial ties. This result is in line with previous studies (Gao et al., 2017; Zhang et al., 2010). According to social network theory, management ties provide significant resources, knowledge, information, and privileges, including exclusive opportunities and legitimacy to entrepreneurs. Moreover, Entrepreneurs benefit from managerial relationships to boost product innovation, capitalize on opportunities, and acquire a competitive advantage. Specifically, according to the institutional theory, SMEs in Vietnam have overcome the intrinsically constrained by utilizing managerial ties to facilitate firm performance. Managers assist an enterprise in building strong network structures and intricate ties with society, as well as obtaining valuable and rare resources from the external environment or interfirm network. Finally, both social media and managerial ties facilitate firm performance. The results are consistent with previous findings (Li, 2005; Park \& Luo, 2001; Parveen et al., 2016). Social media has a greater impact than managerial ties on firm performance. The underlying meaning of this result is that activities on social media have become more and more essential in the era of Internet evolution, affecting every aspect of many business sectors. Social media plays a role in connecting entrepreneurial orientation and firm performance of SMEs. Therefore, SMEs can better promote their products instead of solely attempting to increase their sales via social media platforms, which eventually contributes to improving business performance. In other words, entrepreneurial orientation has an indirect effect on firm performance, in addition to its direct influence on social media and managerial ties.

\section{Conclusions}

To further comprehend the EO-firm performance relationship and the previously reported discrepancies, this study integrates social network theory and institutional theory to explain how social media and managerial ties play an essential role in facilitating firm performance, but previously neglected these mediating effects. Moreover, we differentiate from prior research in building two second-order constructs, including EO and managerial ties. The above empirical results of 180 senior managers of SMEs in Vietnam provide general support for the four proposed hypotheses, except for hypothesis 1. Overall, the findings confirm the indirect EO-firm performance relationship, and the individual and configurational mediators we investigated contribute to a better understanding of how EO generates value. While our research contributes to this vital field, more research is still needed, and as a result, this exciting field is a promising one for future research.

\section{Acknowledgment}

This research is funded by International University, Vietnam National University Ho Chi Minh City (VNU-HCMC) under grant number T2021-01-BA. 


\section{References}

Adler, P. S., \& Kwon, S. W. (2002). Social capital: Prospects for a new concept. Academy of Management Review, 27(1), 17-40. https://doi.org/10.5465/AMR.2002.5922314

Aichner, T., \& Jacob, F. (2015). Measuring the Degree of Corporate Social Media Use. International Journal of Market Research, 57(2), 257-276. https://doi.org/10.2501/IJMR-2015-018

Amin, M. (2015). The effect of entrepreneurship orientation and learning orientation on SMEs' performance: an SEM-PLS approach. Journal for International Business and Entrepreneurship Development, 8(3), 215-230.

Aragón-Sánchez, A., \& Sánchez-Marín, G. (2005). Strategic orientation, management characteristics, and performance: A study of Spanish SMEs. Journal of Small Business Management, 43(3), 287-308. https://doi.org/10.1111/j.1540-627X.2005.00138.x

Buli, B. M. (2017). Entrepreneurial orientation, market orientation and performance of SMEs in the manufacturing industry: Evidence from Ethiopian enterprises. Management Research Review, 40(3), 292-309.

Chatterjee, S., \& Kumar Kar, A. (2020). Why do small and medium enterprises use social media marketing and what is the impact: Empirical insights from India. International Journal of Information Management, 53, 102103. https://doi.org/10.1016/j.ijinfomgt.2020.102103

Cheah, J. H., Memon, M. A., Chuah, F., Ting, H., \& Ramayah, T. (2018). Assessing reflective models in marketing research: A comparison between pls and plsc estimates. International Journal of Business and Society, 19(1), 139-160.

Chen, Y., Fay, S., \& Wang, Q. (2011). The Role of Marketing in Social Media: How Online Consumer Reviews Evolve. Journal of Interactive Marketing, 25(2), 85-94. https://doi.org/10.1016/j.intmar.2011.01.003

Covin, J. G., \& Slevin, D. P. (1989). Strategic management of small firms in hostile and benign environments. Strategic Management Journal, 10(1), 75-87.

De Jong, G., Tu, P. A., \& Van Ees, H. (2012). Which Entrepreneurs Bribe and what do they Get from It? Exploratory Evidence from Vietnam. Entrepreneurship Theory and Practice, 36(2), 323-345. https://doi.org/10.1111/j.1540-6520.2010.00400.x

Dutot, V., \& Bergeron, F. (2016). From strategic orientation to social media orientation: Improving SMEs' performance on social media. Journal of Small Business and Enterprise Development, 23(4), 1165-1190. https://doi.org/10.1108/JSBED-11-2015-0160

Engelen, A., Gupta, V., Strenger, L., \& Brettel, M. (2015). Entrepreneurial Orientation, Firm Performance, and the Moderating Role of Transformational Leadership Behaviors. Journal of Management, 41(4), 1069-1097. https://doi.org/10.1177/0149206312455244

Fornell, C., \& Larcker, D. F. (1981). Evaluating structural equation models with unobservable variables and measurements error. Journal of Marketing Research, 18(4), 39-50. https://doi.org/10.2307/3151312

Gao, Y., Shu, C., Jiang, X., Gao, S., \& Page, A. L. (2017). Managerial ties and product innovation: The moderating roles of macro- and micro-institutional environments. Long Range Planning, 50(2), 168-183. https://doi.org/10.1016/j.lrp.2016.11.005

Gupta, V. K. (2015). Construction of entrepreneurial orientation: Dispute, demand, and dare. New England Journal of Entrepreneurship, 18(1), 87-89.

Hair, J. F., Risher, J. J., Sarstedt, M., \& Ringle, C. M. (2019). When to use and how to report the results of PLS-SEM. European Business Review, 31(1), 2-24. https://doi.org/10.1108/EBR-11-2018-0203

Hajli, M. N. (2014). A study of the impact of social media on consumers. International Journal of Market Research, 56(3), $387-404$. https://doi.org/10.2501/IJMR-2014-025

Henseler, J., Ringle, C. M., \& Sarstedt, M. (2015). A new criterion for assessing discriminant validity in variance-based structural equation modeling. Journal of the Academy of Marketing Science, 43(1), 115-135. https://doi.org/10.1007/s11747-014-0403-8

Hult, G. T. M., \& Ketchen Jr, D. J. (2001). Does market orientation matter?: A test of the relationship between positional advantage and performance. Strategic Management Journal, 22(9), 899-906.

Jiang, X., Liu, H., Fey, C., \& Jiang, F. (2018). Entrepreneurial orientation, network resource acquisition, and firm performance: A network approach. Journal of Business Research, 87, 46-57. https://doi.org/10.1016/j.jbusres.2018.02.021

Karami, M., \& Tang, J. (2019). Entrepreneurial orientation and SME international performance: The mediating role of networking capability and experiential learning. International Small Business Journal: Researching Entrepreneurship, 37(2), 105-124. https://doi.org/10.1177/0266242618807275

Kim, S., \& Park, H. (2013). Effects of various characteristics of social commerce (s-commerce) on consumers' trust and trust performance. International Journal of Information Management, 33(2), 318-332. https://doi.org/10.1016/j.ijinfomgt.2012.11.006

Ladkin, A., \& Buhalis, D. (2016). Online and social media recruitment. International Journal of Contemporary Hospitality Management, 28(2), 327-345. https://doi.org/10.1108/IJCHM-05-2014-0218

Lee, T. (2019). Management ties and firm performance: Influence of family governance. Journal of Family Business Strategy, 10(2), 105118. https://doi.org/10.1016/j.jfbs.2018.12.003

Lee, T., \& Chu, W. (2017). The relationship between entrepreneurial orientation and firm performance: Influence of family governance. Journal of Family Business Strategy, 8(4), 213-223. https://doi.org/10.1016/j.jfbs.2017.09.002

Li, J. J. (2005). The Formation of Managerial Networks of Foreign Firms in China: The Effects of Strategic Orientations. Asia Pacific Journal of Management, 22(4), 423-443. https://doi.org/10.1007/s10490-005-4118-8

Lumpkin, G. T., \& Dess, G. G. (1996). Clarifying the Entrepreneurial Orientation Construct and Linking It To Performance. Academy of Management Review, 21(1), 135-172. https://doi.org/10.5465/amr.1996.9602161568

Luo, Y., Huang, Y., \& Wang, S. L. (2012). Guanxi and Organizational Performance: A Meta-Analysis. Management and Organization Review, 8(1), 139-172. https://doi.org/10.1111/j.1740-8784.2011.00273.x

Luu, N., \& Ngo, L. V. (2019). Entrepreneurial orientation and social ties in transitional economies. Long Range Planning, 52(1), 103-116. https://doi.org/10.1016/j.lrp.2018.04.001

Michaelidou, N., Siamagka, N. T., \& Christodoulides, G. (2011). Usage, barriers and measurement of social media marketing: An exploratory investigation of small and medium B2B brands. Industrial Marketing Management, 40(7), 1153-1159. https://doi.org/10.1016/j.indmarman.2011.09.009

Mount, M., \& Martinez, M. G. (2014). Social media: A tool for open innovation. California Management Review, 56(4), $124-143$.

Naudé, P., Zaefarian, G., Najafi Tavani, Z., Neghabi, S., \& Zaefarian, R. (2014). The influence of network effects on SME performance. Industrial Marketing Management, 43(4), 630-641. https://doi.org/10.1016/j.indmarman.2014.02.004

Nguyen, P. V., Huynh, H. T. N., Lam, L. N. H., Le, T. B., \& Nguyen, N. H. X. (2021). The impact of entrepreneurial leadership on SMEs' performance: the mediating effects of organizational factors. Heliyon, 7(6), 1-13. https://doi.org/10.1016/j.heliyon.2021.e07326 
Nisar, T. M., \& Whitehead, C. (2016). Brand interactions and social media: Enhancing user loyalty through social networking sites. Computers in Human Behavior, 62, 743-753. https://doi.org/10.1016/j.chb.2016.04.042

Olanrewaju, A.-S. T., Hossain, M. A., Whiteside, N., \& Mercieca, P. (2020). Social media and entrepreneurship research: A literature review. International Journal of Information Management, 50, 90-110. https://doi.org/10.1016/j.ijinfomgt.2019.05.011

Park, S. H., \& Luo, Y. (2001). Guanxi and organizational dynamics: organizational networking in Chinese firms. Strategic Management Journal, 22(5), 455-477. https://doi.org/10.1002/smj.167

Parveen, F., Jaafar, N. I., \& Ainin, S. (2016). Social media's impact on organizational performance and entrepreneurial orientation in organizations. Management Decision, 54(9), 2208-2234. https://doi.org/10.1108/MD-08-2015-0336

Peng, M. W. (2003). Institutional Transitions and Strategic Choices. Academy of Management Review, 28(2), $275-296$. https://doi.org/10.5465/amr.2003.9416341

Peng, M. W., \& Luo, Y. (2000). Managemental ties and firm performance in a transition economy: The nature of a micro-macro link. Academy of Management Journal, 43(3), 486-501. https://doi.org/10.2307/1556406

Presutti, M., \& Odorici, V. (2019). Linking entrepreneurial and market orientation to the SME's performance growth: the moderating role of entrepreneurial experience and networks. International Entrepreneurship and Management Journal, 15(3), 697-720. https://doi.org/10.1007/s11365-018-0533-4

Qalati, S. A., Yuan, L. W., Khan, M. A. S., \& Anwar, F. (2021). A mediated model on the adoption of social media and SMEs' performance in developing countries. Technology in Society, 64, 1-12. https://doi.org/10.1016/j.techsoc.2020.101513

Rauch, A., Wiklund, J., Lumpkin, G. T., \& Frese, M. (2009). Entrepreneurial Orientation and Business Performance: An Assessment of past Research and Suggestions for the Future. Entrepreneurship Theory and Practice, 33(3), 761-787. https://doi.org/10.1111/j.15406520.2009.00308.x

Ringle, C.M., Wende, S., \& Becker, J. M. (2018). SmartPLS 3. Boenningstedt: SmartPLS GmbH. 2018. https://doi.org/www.smartpls.com

Ringle, Christian M, \& Sarstedt, M. (2016). Gain more insight from your PLS-SEM results: The importance-performance map analysis. Industrial Management \& Data Systems, 116(9), 1865-1886.

Schaupp, L. C., \& Bélanger, F. (2014). The Value of Social Media for Small Businesses. Journal of Information Systems, 28(1), $187-207$. https://doi.org/10.2308/isys-50674

Sheng, S., Zhou, K. Z., \& Li, J. J. (2011). The Effects of Business and Political Ties on Firm Performance : Evidence from China. Journal of Marketing, 75(1), 1-15. https://doi.org/10.1509/jm.75.1.1

Siamagka, N.-T., Christodoulides, G., Michaelidou, N., \& Valvi, A. (2015). Determinants of social media adoption by B2B organizations. Industrial Marketing Management, 51, 89-99. https://doi.org/10.1016/j.indmarman.2015.05.005

Tajeddini, K., \& Ratten, V. (2020). The moderating effect of brand orientation on inter-firm market orientation and performance. Journal of Strategic Marketing, 28(3), 194-224.

Tajvidi, R., \& Karami, A. (2021). The effect of social media on firm performance. Computers in Human Behavior, $115,105174$. https://doi.org/10.1016/j.chb.2017.09.026

Thanos, I. C., Dimitratos, P., \& Sapouna, P. (2017). The implications of international entrepreneurial orientation, politicization, and hostility upon SME international performance. International Small Business Journal: Researching Entrepreneurship, 35(4), $495-514$. https://doi.org/10.1177/0266242616641749

Trainor, K. J., Andzulis, J. (Mick), Rapp, A., \& Agnihotri, R. (2014). Social media technology usage and customer relationship performance: A capabilities-based examination of social CRM. Journal of Business Research, 67(6), 1201-1208. https://doi.org/10.1016/j.jbusres.2013.05.002

Uzzi, B. (1996). The sources and consequences of embeddedness for the economic performance of organizations: The network effect. American Sociological Review, 61(4), 674-698.

Valos, M., Polonsky, M. J., Mavondo, F., \& Lipscomb, J. (2015). Senior marketers' insights into the challenges of social media implementation in large organisations: assessing generic and electronic orientation models as potential solutions. Journal of Marketing Management, 31(7-8), 713-746.

Venkatraman, N., \& Prescott, J. E. (1990). Environment-strategy coalignment: An empirical test of its performance implications. Strategic Management Journal, 11(1), 1-23. https://doi.org/10.1002/smj.4250110102

Wang, C. L. (2008). Entrepreneurial Orientation, Learning Orientation, and Firm Performance. Entrepreneurship Theory and Practice, $32(4), 635-657$.

Wardati, N. K., \& Mahendrawathi, E. R. (2019). The impact of social media usage on the sales process in small and medium enterprises (SMEs): A systematic literature review. Procedia Computer Science, 161, 976-983.

World Bank. (2020). Small and Medium Enterprises (SMEs) Finance. https://doi.org/https://www.worldbank.org/en/topic/smefinance

Zhang, J., Soh, P., \& Wong, P. (2010). Entrepreneurial Resource Acquisition through Indirect Ties: Compensatory Effects of Prior Knowledge. Journal of Management, 36(2), 511-536. https://doi.org/10.1177/0149206308329963

Zhang, W., Zhao, W., Gao, Y., \& Xiao, Z. (2020). How do managerial ties influence the effectuation and causation of entrepreneurship in China? The role of entrepreneurs' cognitive bias. Asia Pacific Business Review, $26(5), 613-641$. https://doi.org/10.1080/13602381.2020.1765537

Zhou, K. Z., Li, J. J., Sheng, S., \& Shao, A. T. (2014). The evolving role of managerial ties and firm capabilities in an emerging economy: evidence from China. Journal of the Academy of Marketing Science, 42(6), 581-595. https://doi.org/10.1007/s11747-014-0371-z

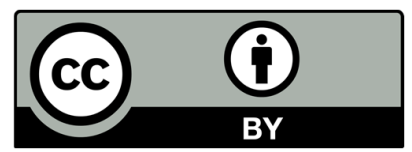

(C) 2022 by the authors; licensee Growing Science, Canada. This is an open access article distributed under the terms and conditions of the Creative Commons Attribution (CC-BY) license (http://creativecommons.org/licenses/by/4.0/). 